\title{
NEGARA KONFEDERASI
}

\author{
NAMA MAHASISWA : FAJAR GEFIN OFARI \\ EMAIL : gefinofari@gmail.com \\ NO BP : : 2010003600018 \\ PERGURUAN TINGGI : UNIVERSITAS EKASAKTI
}




\section{A.PENDAHULUAN}

Negara adalah institusi yang dibentuk oleh kumpulan orang-orang yang hidup dalam wilayah tertentu dengan tujuan sama yang terikat dan taat terhadap perundang-undangan serta memiliki pemerintahan sendiri

Negara dibentuk atas dasar kesepakatan bersama yang bertujuan untuk mengatur kehidupan anggotanya dalam memperoleh hidup dan memenuhi kebutuhan mereka. Untuk mengatur bagaimana anggota masyarakat dalam menjalankan aktivitasnya sebagai warga negara, negara memberikan batasan batasan dalam wujud aturan dan hukum. Dan setiap negara memiliki bentuk bentuk tersendiri

Bentuk negara adalah merupakan batas antara peninjauan secara sosiologis dan peninjauan secara yuridis mengenai negara. Peninjauan secara sosiologis jika negara dilihat secara keseluruhan(ganzhit) tanpa melihat isinya, sedangkan secara yuridis jika negara negara/peninjauan hanya dilihat dari isinya atau strukturnya,sedangkan secara yuridis jika negara/peninjauan hanya dilihat dari isinya atau strukturnya

Dalam makalah ini diterangkan tentang Bentuk Negara Konfederasi ada dan pernah diterapkan didunia ini 


\section{B.PEMBAHASAN}

\section{BENTUK NEGARA KONFEDERASI}

Konfederasi adalah bentuk perserikatan antara negara merdeka berdasarkan perjanjian atau undang-undang misalnya yang menyangkut berbagai kebijakan bersama

Bentuk konfederasi tidak diakui sebagai negara berdaulat tersendiri dalam hukum internasional, karena masing-masing negara yang membentuk konfederasi tetap memiliki kedudukan internasional sebagai negara berdaulat. Contoh dari konfederasi antara lain Perserikatan Bangsa Bangsa dan ASEAN

Konfederasi dapat diartikan juga sebagai bentuk perkembangan selanjutnya dari bentuk Negara Federal. Negara ini dibentuk sebagai perserikatan antara negara-negara atau gabungan beberapa negara untuk membuat sebuah system kehidupan bersama yg lebih besar lagi.unsur pembentuknya bukan koloni lagi atau kelompok-kelompok masyarakat akan tetapi negara dalam pengertiannya yang harafiah. Dapat dikatakan bahwa negara konfederasi adalah negara yang berbentuk negara. Dalam hukum internasional, negara konfederasi tidak diakui sebagai negara berdaulat,karena negara-negara yang membentuknya telah memiliki kedudukan internasional sebagai negara berdaulat sebelumnya

Konfederasi merupakan gabungan dari sejumlah negara melalui sejumlah perjanjian internasional yang memberikan wewenang tertentu kepada konfederasi. Dalam bentuk gabungan ini,negara negara anggota konfederasi masing masing nya tetap merupakan negara negara yang berdaulat dan subjek hukum internasional. Bentuk konfederasi hanya di abad XIX, Walaupun swiss secara resmi menamakan dirinya sebagai konfederasi tetapi semenjak tahun 1848 hakekatnya lebih banyak bersifat federal dimana wewenang luar negeri berada ditangan pemerintah federal

Pendapat para ahli tentang Negara konfederasi:

\section{Jellinek}

Menurut jellinek,perbedaan antara negara konfederasi dengan negara serikat adalah dalam masalah kedaulatan yaitu:

a. Pada negara konfederasi terletak pada negara negara yang berserikat

b. Pada negara serikat terletak pada negara secara keseluruhan

Pendapat Jellinek tersebut berbeda dengan pendapat dengan Kranenburg, kranenburg menyatakan bahwa apabila kedaulatan dipandang dalam arti kata absolut yaitu kekuasaan mutlak sebagai kelengkapan semua kekuasaan, maka dalam negara konfederasi kedaulatan tidak seluruhnya terletak dalam tangan negara-negara yang berserikat dan selalu masih terlihat sedikit kekuasaan pada negara konfederasi tersebut

\section{Kranenburg}

Menurut kranenburg perbedaan antara negara konfederasi dengan negara serikat adalah dapat dilihat dalam ukuran terikat atau tidaknya rakyat negara-negara yang berserikat secara langsung dengan peraturan-peraturan dari negara konfederasi tersebut,dalam arti : 
a. Pada negara konfederasi,alat alat perlengkapannya mempunyai kekuasaan dan kewajiban terhadap yang berserikat yang telah teratur tersebut

b. Pada negara serikat,alat alat pusat punya mempunyai kekuasaan dan kewajiban langsung mengenai rakyatnya

\section{L. Oppenheim}

Menurutnya negara konfederasi terdiri dari beberapa negara yang berdaulat penuh yang untuk mempertahankan kemerdekaan ekstern dan intern, bersatu atas dasar perjanjian internasional yang diakui dengan menyelenggarakan beberapa alat perlengkapan tersendiri yang mempunyai kekuasaan tertentu terhadap negara anggota konfederasi tetapi tidak terhadap warga negara dari negara yang mengadakan konfederasi tersebut

Perbedaan negara konfederasi dengan negara federasi adalah sebagai berikut :

a. Negara federasi yakni adanya satu negara besar yang berfungsi sebagai negara pusat dengan satu konstitusi federal yang didalamnya terdapat sejumlah negara bagian yang masing masing memiliki konstitusinya sendiri-sendiri. Konstitusi negara bagian yang masing masing memiliki konstitusi nya sendiri sendiri.konstitusi federal adalah mengatur batas batas kewenangan pusat sedangkan sisanya dianggap sebagai milik daerah

b. Negara konfederasi yakni adanya banyak negara, yang memiliki konstitusi sendiri sendiri tetapi bersepakat untuk bergabung dalam perhimpunan longgar yang didirikan bersama sama dengan nama konfederasi. Dalam konfederasi kedaulatan terletak di negara negara bagian,.keputusan pemerintah federal mengikat tetapi konfederasi tidak. Negara konfederasi merupakan gabungan antar negara-negara yang telah berdaulat dengan mempergunakan satu satunya perangkat yang dimiliki,yaitu kongres.artinya negara negara dalam konfederasi tersebut tetap memiliki kedaulatan dan konstitusinya sendiri sendiri namun pemerintahan yang berdaulat di tiap negara itu bersepakat untuk duduk satu meja memikirkan segala sesuatu kemungkinan kerjasama dalam forum yang dinamakan kongres tersebu. Jadi bentuk negara konfederasi ini adalah bentuk yang lebih lunak dari federasi,sementara itu antara federasi dan konfederasi dapat dibedakan dari segi letak kedaulatan negara dan kewenangan dalam mengambil keputusan yang mengikat warga negara. Dalam federasi,kedaulatan terletak dipusat. Negara federasi adalah wewenang tertentu hanya bisa dilakukan oleh pemerintah federal,negara konfederasi,wewenang tersebut dapat dilakukan secara bersama sama sesuai dengan pembicaraan bersama.satu satunya negara didunia ini saat ini yang masih menganut sistem konfederasi ialah swiss. Dan amerika pun pernah menerapkan sistem konfederasi ini sebelum terbentuknya negara federal 


\section{C.SIMPULAN}

Konfederasi adalah bentuk perserikatan antara negara merdeka berdasarkan perjanjian atau undang undang misalnya yang menyangkut berbagai kebijakan bersama

Bentuk konfederasi tidak diakui sebagai negara berdaulat tersendiri dalam hukum internasional,karena masing masing negara yang membentuk konfederasi tetap memiliki kedudukan internasional sebagai negara berdaulat

Contoh dari konfederasi antara lain perserikatan bangsa bangsa dan ASEAN

\section{DAFTAR PUSTAKA}

Darmini Roza dan Laurensius Arliman S Peran Pemerintah Daerah Di Dalam Melindungi Hak Anak Di Indonesia, Masalah-Masalah Hukum, Volume 47, Nomor 1, 2018.

Laurensius Arliman S, Komnas HAM dan Perlindungan Anak Pelaku Tindak Pidana, Deepublish, Yogyakarta, 2015.

Laurensius Arliman S, Penguatan Perlindungan Anak Dari Tindakan Human Trafficking Di Daerah Perbatasan Indonesia, Jurnal Selat, Volume 4, Nomor 1, 2016.

Laurensius Arliman S, Problematika Dan Solusi Pemenuhan Perlindungan Hak Anak Sebagai Tersangka Tindak Pidana Di Satlantas Polresta Pariaman, Justicia Islamica, Volume 13, Nomor 2, 2016.

Laurensius Arliman S, Pelaksanaan Perlindungan Anak Yang Tereksploitasi Secara Ekonomi Oleh Pemerintah Kota Padang, Veritas et Justitia, Volume 2, Nomor 1, 2016.

Laurensius Arliman S, Kedudukan Ketetapan MPR Dalam Hierarki Peraturan PerundangUndangan Di Indonesia, Lex Jurnalica, Volume 13, Nomor 3, 2016.

Laurensius Arliman S, Komnas Perempuan Sebagai State Auxialiary Bodies Dalam Penegakan Ham Perempuan Indonesia, Justicia Islamica, Volume 14, Nomor 2, 2017. 
Laurensius Arliman S, Peranan Pers Untuk Mewujudkan Perlindungan Anak Berkelanjutan Di Indonesia, Jurnal Ilmu Hukum Tambun Bungai, Volume 2, Nomor 2, 2017.

Laurensius Arliman S, Mewujudkan Penegakan Hukum Yang Baik Untuk Mewujudkan Indonesia Sebagai Negara Hukum, Jurnal Hukum Doctrinal, Volume 2, Nomor 2, 2017.

Laurensius Arliman S, Participation Non-Governmental Organization In Protecting Child Rights In The Area Of Social Conflict, The 1st Ushuluddin and Islamic Thought International Conference (Usicon), Volume 1, 2017.

Laurensius Arliman S, Partisipasi Masyarakat Dalam Pembentukan Perundang-Undangan Untuk Mewujudkan Negara Kesejahteraan Indonesia, Jurnal Politik Pemerintahan Dharma Praja, Volume 10, Nomor 1, 2017, https://doi.org/10.33701/jppdp.v10i1.379.

Laurensius Arliman S, Peran Komisi Perlindungan Anak Indonesia Untuk Mewujudkan Perlindungan Anak, Jurnal Respublica Volume 17, Nomor 2, 2018.

Laurensius Arliman S, Menjerat Pelaku Penyuruh Pengrusakan Barang Milik Orang Lain Dengan Mempertimbangkan Asas Fungsi Sosial, Jurnal Gagasan Hukum, Volume 1, Nomor 1, 2019.

Laurensius Arliman S, Ilmu Perundang-Undangan Yang Baik Untuk Negara Indonesia, Deepublish, Yogyakarta, 2019.

Laurensius Arliman S, Isdal Veri, Gustiwarni, Elfitrayenti, Ade Sakurawati, Yasri, Pengaruh Karakteristik Individu, Perlindungan Hak Perempuan Terhadap Kualitas Pelayanan Komnas Perempuan Dengan Kompetensi Sumber Daya Manusia Sebagai Variabel Mediasi, Jurnal Menara Ekonomi: Penelitian dan Kajian Ilmiah Bidang Ekonomi, Volume 6, Nomor 2, 2020.

Laurensius Arliman S, Pendidikan Kewarganegaraan, Deepublish, Yogyakarta, 2020.

Laurensius Arliman S, Makna Keuangan Negara Dalam Pasal Pasal 23 E Undang-Undang Dasar 1945, Jurnal Lex Librum, Volume 6, Nomor 2 Juni 2020, http://dx.doi.org/10.46839/11jih.v6i2.151. 
Laurensius Arliman S, Kedudukan Lembaga Negara Independen Di Indonesia Untuk Mencapai Tujuan Negara Hukum, Kertha Semaya Journal Ilmu Hukum, Volume 8, Nomor 7, 2020.

Laurensius Arliman S, Pelaksanaan Assesment Oleh Polres Kepulauan Mentawai Sebagai Bentuk Pelaksanaan Rehabilitasi Bagi Pecandu Dan Korban Penyalahgunaan Narkotika, Jurnal Muhakkamah, Volume 5, Nomor 1, 2020.

Laurensius Arliman S, Aswandi Aswandi, Firgi Nurdiansyah, Laxmy Defilah, Nova Sari Yudistia, Ni Putu Eka, Viona Putri, Zakia Zakia, Ernita Arief, Prinsip, Mekanisme Dan Bentuk Pelayanan Informasi Kepada Publik Oleh Direktorat Jenderal Pajak, Volume 17, No Nomor, 2020.

Larensius Arliman S, Koordinasi PT. Pegadaian (Persero) Dengan Direktorat Reserse Narkoba Polda Sumbar Dalam Penimbangan Barang Bukti Penyalahgunaan Narkotika, UIR Law Review, Volume 4, Nomor 2, 2020, https://doi.org/10.25299/uirlrev.2020.vol4(1).3779.

Laurensius Arliman S, Tantangan Pendidikan Kewarganegaraan Pada Revolusi 4.0, Ensiklopedia Sosial Review, Volume 2, Nomor 3, 2020.

Muhammad Afif dan Laurensius Arliman S, Protection Of Children's Rights Of The Islamic And Constitutional Law Perspective Of The Republic Of Indonesia, Proceeding: Internasional Conference On Humanity, Law And Sharia (Ichlash), Volume 1, Nomor 2, 2020.

Otong Rosadi danLaurensius Arliman S, Urgensi Pengaturan Badan Pembinaan Idelogi Pancasila Berdasarkan Undang-Undang Sebagai State Auxiliary Bodies yang Merawat Pancasila dalam Perspektif Hak Asasi Manusia, Prosiding Konferensi Nasional Hak Asasi Manusia, Kebudayaan dan Tujuan Pembangunan Berkelanjutan Indonesia pada Masa Pandemi Covid-19: Tantangan untuk Keilmuan Hukum dan Sosial Volume 1, Universitas Pancasila, Jakarta, 2020. 
